woody strand, simple veinless leaves, and, probably, dehiscent sporangia borne on special axes. These three genera, together with impressions of the Psilophyton.type, have been grouped into a new class, the Psilophytales, showing relationship with higher Pteridophytes, and also suggesting derivation from algæ.

The demonstration of these plants occupied most of the time, but a few other specimens were examined, including those of Glossopteris collected near the South Pole by the ill-fated members of Capt. Scott's last expedition, and those illustrating the Tertiary flora of the Arctic.

\title{
VISIT TO THE GALLERY OF FOSSIL FISHES, BRITISH MUSEUM (NATURAL HISTORY).
}

SATURday, FFbRLARY 26Th, Ig2I.

Demonstration and Report by Dr. A. Smith Woodward, F.R.S.

DR. Woodward referred to recent progress in the study of fossil fishes, and pointed out some of the specimens illustrating it.

The earliest known fish-remains are fragments of scales and dermal plates in bone-beds of Ordovician age in Colorado, Montana, and South Dakota, U.S.A. Microscope-sections of the small plates named $A$ straspis have lately been made in the Museum and seem to show that they belong to a primitive Ostracoderm related to Cephalaspis.

A nearly complete specimen of Phyllolepis concentrica found in the Upper Old Red Sandstone of Dura Den, Fifeshire, in I9I2, proves that Phyllolepis (Fig. 20) is an Ostracoderm allied to Drepanaspis (Fig. 2I). There can now be no doubt that Traquair was mistaken in his determination of the dorsal and ventral aspects of the latter genus, actually reversing them. Such a mistake by so experienced an observer illustrates the difficulty of interpreting some of the unfamiliar early fossil fishes.

Renewed studies of the Palaozoic sharks and skates emphasise the distinctness of the old from the modern groups, and show that there are more marks of evolution among the Elasmobranch fishes than was formerly supposed. The shark, Cladoselache, represented in the Museum by a fine collection from the Upper Devonian of Ohio, U.S.A., is especially primitive. Even the Mesozoic shark, Hybodus, which seems so closely similar to the existing Port Jackson shark, Cestracion, has a widely different skull, much more resembling that of Notidanus, as shown by the beautiful series of specimens collected by S. H. Beckles, from the Wealden of Pevensey Bay. At the same time some modern sharks and skates, such as Crossorhinus, Squatina, and Rhinobatus are typically represented by nearly complete well-preserved 
specimens in the Upper Jurassic lithographic stone of Germany and France. Many modern forms occur in the Cretaceous, although some of them, such as Scapanorhynchus, are now rare and have retreated to great depths in the sea. Plychodus is the most striking characteristically Cretaccous genus, represented by groups of teeth from the English Chalk. It must have been a kind of large skate related to the existing sting-rays and devil-fishes.

Among Tertiary sharks known only by teeth and vertebræ,

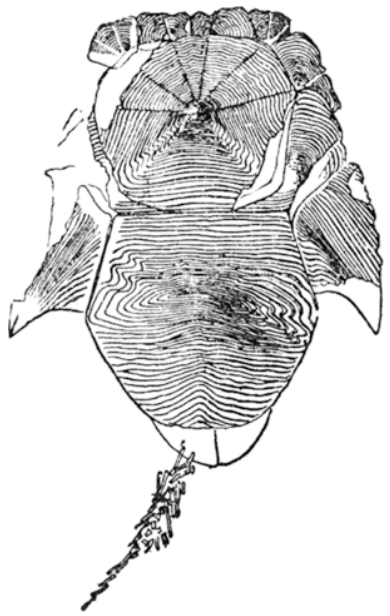

Phylloleits.

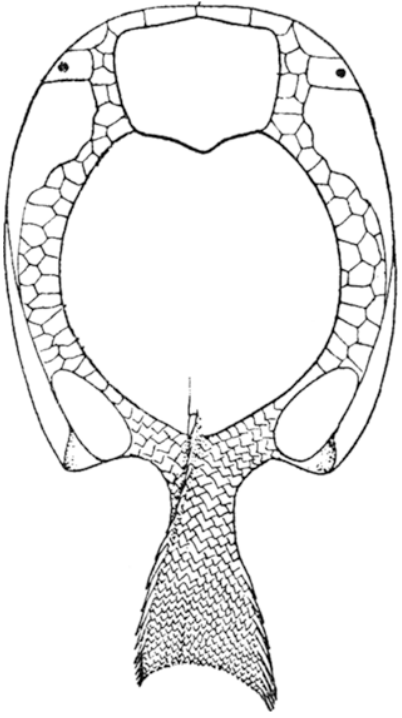

DREPANASPIS.

FIG. 20.-Drawing of nearly complete fossil of Phyllolepis concentrica, dorsal aspect, from the Upper Old Ked Sandstone, Dura Den, Fifeshire, about one-third nat. size. The axial skeleton of the scaleless tail is scen.

FIG. 2 I.- Restoration of Drepanaspis gemuendenensis, dorsal aspect, from the Lower Devonian of Gmünden, Eifel, Germany, about onequarter nat. size.

[From Proc. Linn. Soc., I919-20.]

efforts have lately been made to determine the variations of the teeth in different parts of the jaws. Sets of teeth of the familiar Notidanus primigenius, Odontaspis elegans, O. macrota and $O$. cuspidata are thus exhibited.

Additions have been made to our knowledge of the distribution of the teeth of the Dipnoan mud-fish Ceratodus, and new specimens are exhibited. It appears that this was a widely distributed marine fish until the Cretaceous period, and only took refuge in fresh waters in the Tertiary. The three existing Dipnoan genera, Ceratodus of Australia, Lepidosiren of South 
America, and Protopterus of Africa, seem to have survived only because they became refugees in fresh water.

The scales of Holoptychius and plates of Bothriolepis obtained from a boring at Southall, Middlesex, by Mr. Ernest Proctor, are interesting as proving the occurrence of typical Upper Old Red Sandstone in this area.

Among additions to Mesozoic ganoids, the fine specimens of Lepidotus mantelli discovered by the late Mr. Charles Dawson in the Wealden of Hastings, are especially important. The internal skeleton is very slightly ossified, but the enamelled scales and dermal plates are remarkably thick.

The Pycnodont fishes, to which valuable additions have lately been made, are closely related to Lepidotus, though shaped outwardly like the existing coral-fishes. Fishes exactly adapted for life among coral reefs have arisen at least three times-the Platysomidre from the Acipenseroids of the Carboniferous, the Pycnodontidie from the Lepidotoids of the Jurassic, and the Chætodontidæ, Balistidæ, \&c., from the Teleostean fishes of the earliest Tertiary.

The finest of the latest additions to the Crctaceous fishes is a nearly complete skeleton of Portheus molossus from the Chalk of Kansas, I3 feet in length. This and several other Cretaceous fishes are interesting because, although they have so modern an aspect, they do not fall preciscly within any one existing family but combine the characters of two or more. Many are related to fishes which have now taken refuge in the deep sea. That most of the Cretaceous forms lived in comparatively shallow water is proved by the stoutness of their bones.

Shoals of fossil fishes have lately been found in a thick marine deposit of diatoms, probably Miocene, in Santa Barbara Co., California. A shoal of herrings ( $X y n e$ grex) is exhibited. Our knowledge of fossil fishes still depends very largely on the discovery of such shoals which have been suddenly destroyed by local accidents and then rapidly buried.

\section{EXCURSION TO KINGSTON HILI.}

Saturday, March 5TH, I92I.

\section{Report by ERnest Arthur Turner, F.G.S., Director of the Excursion.}

THE large gravel pit on the Fitz-George Estate at Coombe, Kingston Hill, was visited by the Association in 1917 , and readers are referred to the report of that excursion by Mr. C. J. Grist for other details and a map.

On this occasion some 36 members visited the section, and the Association is again indebted to Mr. Harold Bailey, the agent, 